\title{
From Politicization to Securitization of Maritime Security in the Gulf of Guinea
}

\author{
João Piedade
}

\section{Abstract}

EU's Energy security and trade depend, to a large extent, on sea-based transport relying on open sea lines of communication and Maritime Security. The Gulf of Guinea (GoG) region has supplied 13 per cent of oil and six per cent of total EU28 consumption. Between 2003 and January 2015, piracy in the GoG accounted for 31 per cent of attacks $(616$ of 1,965) in African waters. With that proportion on the rise and a growing threat related to Piracy, illegal over-fishing and crude oil theft; maritime (in)security in the region is attracting attention from regional and international governments and bodies.

In this context, and considering politicization as a more extreme version or a step to securitization, this paper analyses how an issue is brought up to the level of security by a speech act, namely, explaining how issues are politicized and securitized within the maritime domain and what strategies are involved.

A number of institutions are currently acting to secure the Gulf of Guinea with growing co-operation between the region and extra-regional actors. However, the lack of capabilities, weak governance within the region and the willingness to take action from extra-regional actors have undermined the securitization, and thus, the Gulf of Guinea has remained politicized.

\section{KEY WORDS:}

Politicization, Securitization, Maritime Security, Gulf of Guinea 


\section{Introduction: Securitization of Maritime Security}

On April 2015, the G7 conference of foreign ministers on Maritime Security acknowledged that international security and stability, human development, generation of economic growth and prosperity, secure energy supply and preservation of ecological diversity depend on a safe, sound and secure maritime domain (G7 2015).

As the world's population grows, our reliance on the good order at sea increases, with the proportion of trade by sea growing significantly (Vrey 2011 : 59). Keeping open sea lines of communication is vital for humankind, permitting transport and trade to enhance further human development (Vrë̈ 2009: 18).

Good order at sea is maintained through the policed enforcement of regulations and laws, such as those emanating from the Convention on Law of the Sea (UNCLOS) and Exclusive Economic Zone (EEZ) stipulations. Threats that fall beyond their scope, or that are not being addressed due to bad order or to lack of capability from the states, have to be securitized (Vreÿ 2011:59).

The proliferation of incidents of violence at sea off the coast of Western and Central Africa between the years of 2006 and 2010 has led this region to become a major hotspot of piracy in Africa, alongside the Indian Ocean Region. The maritime crime figures for the first quarter of 2016, reported by Dryad Maritime, indicate that this region has become the world's leading hotspot, with 31 incidents reported and 37 crew members kidnapped. Western and Central Africa is a major concern for international maritime trade, with a serious impact on international oil and natural resource business, as well as on the interregional economy. Thus, there is a need to increase the level of awareness of the threat posed by maritime (in)security.

Between 2006 and 2010, the International Maritime Bureau recorded 29 attacks in Nigerian waters, leading the region to become the new major piracy hotspot in Africa (Otto 2014: 313). Between 2003 and January 2015, International Maritime Organization (IMO) recorded the occurrence in 
the GoG of 31 per cent of piracy attacks $(616$ of 1,965$)$ accounted in African waters.

Reporting on piracy in the Eastern Coast of Africa, the United Nations led a process of securitization of piracy, implementing several resolutions (Vrey 2011: 64; Oliveira 2015: 132) and permitting the operation of international naval assets within the Somali territorial waters to counter the threats posed to open sea lines of communication and human security at sea.

This paper analyses the process of securitization and the path taken, from being ignored to the level of being accepted as an existential threat, and concludes examining at what level (in the process of securitization) the issue of Maritime Security in the Gulf of Guinea is. The argument, supported by the theory of securitization, states that a process of securitization of Maritime Security in the Gulf of Guinea was started and is on the move, however, has not reached the securitization level and the desired effect, thus, not permitting the audience acceptance of the implementation of emergency measures or the breaking of rules.

The paper is structured in four sections. The first examines the concepts of security and securitization and explains what securitization moves are made from politicization to securitization. The second section briefly introduces the concept of Maritime Security and how it can be related to the concept of security. In the third section, the process of securitizing an issue in the maritime domain is analyzed, revisiting the process that occurred in Somalia with the securitization of piracy. Finally, in the last section, the region of the Gulf of Guinea is characterized, the threats within the maritime domain identified and the securitization process compared to the one that occurred in Somalia.

\section{Security, Securitization and Securitization Moves}

In order to understand the concept of Maritime Security and if there is a process of securitization of this issue, it is necessary to introduce some concepts, such as security and securitization. 
(2) During the period of the Cold War, the concept of security was neglected (Baldwin 1997: 8). In 1983, Barry Buzan reinitiated the debate, acknowledging that the extensive use of the term "security" remained underdeveloped (Buzan 1983: 3), ambiguous and contested (Buzan 1983: 6; Booth 2007: 99).

In the tradition of realism, the concept of security, consecrated in the legacy of Machiavelli, Hobbes and Clausewitz, assumes the state as the referent object. The state is responsible for the security of is citizens, assuming the National Security (defence of sovereignty, integrity, values and state interests) as the principal level of security, converting national interest in National Security, as in the case of the US National Security Act, published in 1947 (Williams 2008: 7).

With the foundation of the United Nations in 1945, it seemed that a change in the paradigm was coming, with the security focus moving to the individual, as it can be perceived from the wording of the article 55 of the Charter of the United Nations, which states the necessary conditions for stability necessary for peaceful and friendly relations among nations as being based on the respect for the principle of equal rights and selfdetermination of peoples that can be attainable with the promotion of measures centred on the individual, such as the higher standards of living, full employment and conditions of economic and social progress and development, universal respect for and observance of human rights and fundamental freedoms for all (United Nations 1945).

However, this new approach, claimed by a liberalist line, did not refocus the object of security; instead, it introduced the concept of collective security, in which a group of states that share common values and ideals organizes itself to face a common military threat, thus maintaining the state as the referent object.

To understand the concept of security, it is important to revisit the conceptual analysis made by Wolfers in his article published in 1952, probably one of the first to analyse this concept in depth. In his words, security can be defined as a value "of which a nation can have more or less and which it can aspire to have in greater or less measure" (Wolfers 1952: 484), therefore, it can be achieved in the absence of threats, allowing 
establishment of the necessary conditions to acquire other values, such as material resources or the control of the actions of others.

Baldwin considered that Wolfers' characterization of security as "the absence of threats to acquired values" brought some ambiguity in the phrase "absence of threats" and reformulated it as "a low probability of damage to acquired values", focusing on the preservation of acquired values and not on the presence or absence of "threats", allowing expansion of the threats beyond the military, permitting the inclusion of events such as natural disasters. With this reformulation, security can be defined in two specifications: "Security for whom? And security for which values?" (Baldwin 1997: 13).

In the Cold War period, security paradigm remained centred around the state: it was the actor, detained the power, settled the interests and signed treaties. The end of the Cold War brought back the debate and recast the security agenda, taking the focus out of the military threat and widening the concept to other sectors and levels of analysis. Walt's article "The Renaissance of Security Studies" acknowledged the applicability of security studies to different levels of analysis, considering that they explore the way the use of force can affect individuals, states and societies (1991: 212), however, the focus remained on the military threat, as he stated: "the main focus of security studies is (...) the phenomenon of war". Kolodziej (1992: 421) criticized Walt's perspective, considering that it is restrictive and remains focused on the state and on the military dimension of security. He affirms that security studies cannot be confined to the analysis of the use of force and violence, that it must be inclusive, widening the concept in order to integrate the study of non-violent human behaviours.

In 1983, Barry Buzan, picking up Walt's idea of a three-level analysis, proposed considering the concept of security as relational, interdependent and with connections between the three levels of analysis - the individual, the state and the international system (Buzan 1983: 13), widening the sectors or dimensions of security beyond the military (military, political, economic, social and environmental).

The political debates in the 90s, focused on the content and priorities of security and defence policies, identified the main issue in the field 
of security studies as the analysis of the political process that builds the perception of threat and what the issues emerging in the security agenda are. From this discussion, a new concept emerged: securitization. Originally proposed by Buzan, Weaver and de Wildea (1998), this concept states that a securitizing actor, by means of speech act, can induce to an audience the perception of priority and urgency of an existential threat, meaning that an argument with particular rhetoric can achieve sufficient effects to make an audience voluntarily accept and legitimize the actor's breaking of the rules that otherwise would have to be obeyed (Buzan, Weaver and de Wilde 1998: 25).

An actor that presents an argument of an object as an existential threat to an audience is making a securitization move, which does not by itself create securitization. When the argument reaches sufficient effect, legitimizing emergency measures or breaking of rules, made possible only by the audience's acceptance of the existential threat, then the object is securitized (ibid: 25).

When an actor uses rhetoric to present an argument and declares to an audience that an object of security is existentially threatened (Vreÿ 201 1: 56), depending upon circumstances and acceptance, the issue can be located or end up on the spectrum ranging from non-politicized, through politicized, to securitized (see Figure 1) (lbid: 23).

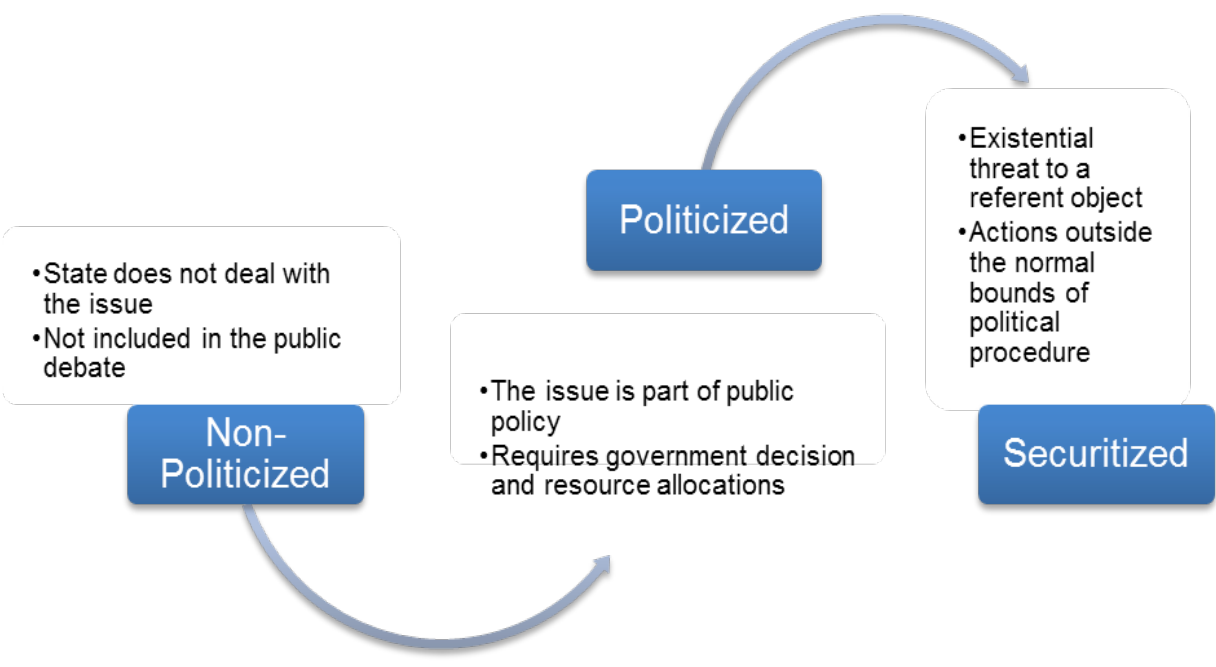

Figure 1 - Securitization moves 
Considering the threats and number of actors involved, Maritime Security meaning will vary across actors, time and space (Bueger 2015: 163). Thus, macrosecuritization must be considered when analysing the moves of securitization of Maritime Security. Macrosecuritization process is defined by the same rules that apply to other securitization processes (Buzan and Weaver 2009: 257). The key difference is that they are on a larger scale and seek to package together securitizations, integrating multiple actors, audiences and objects of reference within a "higher" and larger order (Oliveira 2015: 132).

\section{Maritime Security}

Between 1960 and 1983, there were 111 listed events against maritime targets related to terrorism, piracy and other criminal acts (Jenkins et al. 1983: 6). However, it was in the sequence of the high jacking of the Italian cruise ship Achille Lauro in October of 1985 that the International Maritime Organization (IMO) adopted a series of resolutions, with the objective to prevent illicit acts against the passengers and crews of ships' and to ensure the security of the maritime navigation. ${ }^{23}$

Till (2009:3) highlighted the maritime dimension of globalization, recognizing that it depends absolutely on the free flow of sea-based shipping. He also recognized the need to secure a sea-based globalization potentially vulnerable to disruption. Acknowledging the benefits and threats to maritime navigation early in the 21 st century, the maritime issues became a greater security focus (Vrey 2011: 58). In this context, the absence of Maritime Security can pose an existential threat to globalization.

Is Maritime Security an international security issue? Security is about survival, and when an issue is presented as posing an existential threat to a designated referent object, and the nature of the threat justifies the use

\footnotetext{
Measures to prevent unlawful acts against passengers and crews on board ships (MSC/Circ. 443).

2 Convention for the Suppression of Unlawful Acts against the Safety of Maritime Navigation (SUA).

3 International Ship and Port Facility Security Code (ISPS Code).
} 
of extraordinary measures to handle them, opening the way for the state to mobilize or to take special powers to handle existential threats (Buzan, Weaver and de Wilde 1998: 21), we are dealing with an international security issue.

The concept of Maritime Security can be characterized as embracing and diffuse. In fact, to maintain the security of the maritime domain has become a task that gathers several international entities from the public and private sector with a common goal to achieve order at sea, maintaining the free circulation of persons and goods (Feldt, Roell and Thiele 2013: 2).

The analysis of the requirements to achieve "good order at sea", made by Till (2009: 287), pinned down five attributes: good order from the shore, the sea as a resource, the sea as a medium of transportation, the sea as an area of dominion and the sea as an environment. He also correlated the corresponding threats of disorder to the third attribute: the sea as a medium of transportation. Considering this, identifying the threats and vulnerabilities to the good order at sea has become vital to maintaining freedom of navigation. Although the piracy hype, currently the most visible of the threats to good order at sea, is hardly a credible collective term for such threats and tends to obscure the emergent insecurity in the maritime domain (Vreÿ 2009: 19). Where the state is unable or failing to maintain good order at sea, the list of crimes that have a maritime dimension increases and includes maritime terrorism, trafficking of narcotics, people and illicit goods, arms proliferation, illegal fishing, dumping and other environmental crimes, with the effects of these crimes felt by coastal communities, seafarers and the maritime industry at large.

Scholars and organizations have tried to find a suitable definition of Maritime Security. The international organizations mainly followed Wolfers approach to security, using the argument that Maritime Security should be defined as the absence of these threats. Although there is no consensus on the threats identified, they refer to threats such as maritime inter-state disputes, maritime terrorism, piracy, trafficking of narcotics, people and illicit goods, arms proliferation, illegal fishing, environmental crimes or maritime accidents and disasters (Bueger 2015: 159). 
Correlating Till's attributes of good order at sea with the threats to maritime security and Buzan's dimensions of security, we can obtain the dimensions of maritime security (see Figure 2).

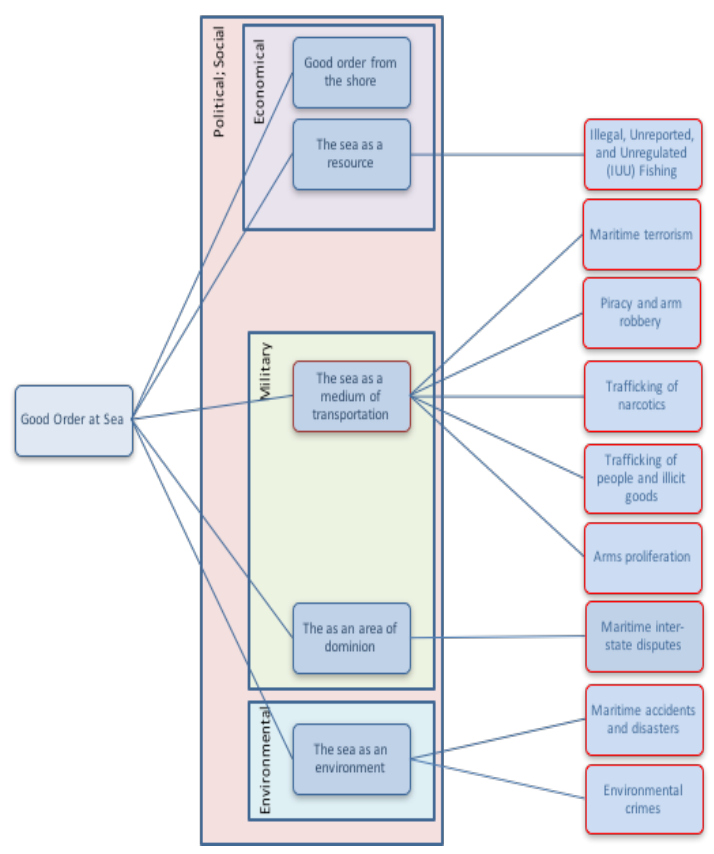

Figure 2 - Dimensions of Maritime Security

\section{Securitization of Maritime Security}

According to Bueger (2015: 164), it is possible to frame Maritime Security in the concept of securitization. One way it could be done is through an analysis of how some issues in the Maritime Security agenda have been securitized, determining what issues have been securitized, to what target audience and what the referent objects are. Thus, the question of what the reference objects are that should be protected from the threats to maritime safety can reveal the political interests at stake. 
Vrey (2011: 64) argues that the events off the Horn of Africa demonstrate a process of securitization within the United Nations (UN) to confront a growing security threat at sea. His argument is supported by the fact that through the promulgation of several resolutions, the UN presented piracy as an existential threat to the flow of food by sea to the displaced Somali society, legitimizing the mobilization of international naval forces to handle the threat and promote good order at sea.

Oliveira goes deeper in identifying the process of securitization of piracy in Somalia, arguing that a process of macrosecuritization has ocurred, integrating multiple actors and objects of reference, targeting multiple audiences at different levels of analysis, with the United Nations Security Council (UNSC) as the "higher-level" audience (Oliveira 2015: 122). The UNSC accepted piracy as a threat to good order at sea and a physical threat to environment, human life and propriety (Oliveira 2015: 131). The effect of the acceptance led to the promulgation of a resolution (UNSC 2008), allowing naval assets to enter the territorial waters of Somalia and use "all necessary means" to repress acts of piracy and armed robbery at sea. The state's acceptance of the threat legitimized the mobilization of naval assets, taking on the special powers given by the UNSC resolution, to handle the existential threats posed by piracy.

\section{Securitizing Maritime Security in the Gulf of Guinea}

The region of the GoG is fast emerging as an important region because of its abundant reserves of mineral and marine resources, combined with the potential market offered by its large population (Vreÿ 2009: 23). Presently, nearly 70 per cent of Africa's oil production is concentrated in the region. Prospectives indicate that by 2020, oil production of the Gulf of Guinea is expected to surpass the total production of the Persian Gulf nations and reach 25 per cent of the world global oil production (Rinkel 2015: 4-5). Currently, the European Union (EU28) meets 13 per cent of its oil and six per cent of its gas needs through resources from the GoG (Barrios 2013: 92). 
Keeping shipping lanes open and safe is vital for transportation and trade, permitting the exchange of information and goods to further human development (Vreÿ 2009: 18). With the exception of Nigeria, few if any of the littoral states in the Gulf of Guinea have the means to enforce governance over their maritime sovereignty (Vreÿ 2009: 25). Hence, the lack of capacity (including resources and training) to protect themselves (UNODC 2013: 53) makes the region extremely vulnerable to illicit commercial fishing, overfishing and unseaworthy navigation (Rinkel 2015: 4-5), traffickers and violent actions at sea, such as armed robbery and piracy.

With the growing importance of this region, world economy and energy security will depend on good order at sea and Maritime Security in the Gulf of Guinea. Walker (2013: 85) acknowledges that there is an international focus on improving security in the region.

The success of international intervention in the Gulf of Aden was followed by the decline of incidents of armed robbery at sea and piracy, now on the rise in the Gulf of Guinea (Barrios 2013: 92). Between 2006 and 2010, the International Maritime Bureau recorded 29 attacks in Nigerian waters, leading the region to become the new major piracy hotspot in Africa (Otto 2014: 313). International Maritime Organization (IMO) recorded, between 2003 and January 2015, the occurrence in the GoG of 31 per cent of piracy attacks $(616$ of 1,965) accounted in African waters, with the incidents on International Waters (IW) on the rise since 2008 and even surpassing those on Territorial Waters (TTW) in 2011 (see Figure 3).

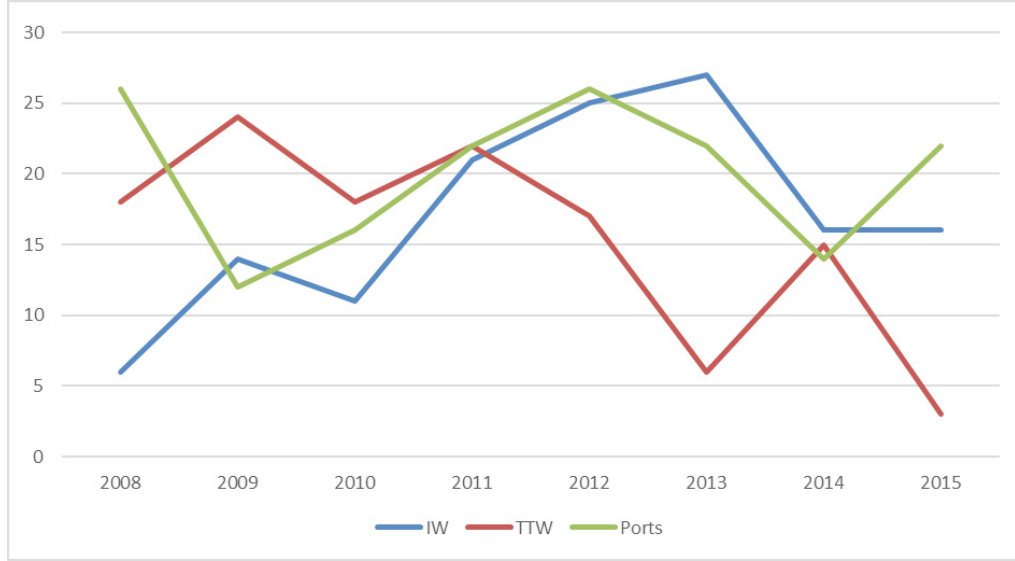

Figure 3 - Maritime Incidents in Western and Central Africa (2008-2015) 
Much has been said about the territorial nature of Nigerian piracy, with manifestations on Nigerian waters and offshore and the waters of neighbouring countries (Otto 2014: 314). Under reporting may impact on the characterization of violent acts at sea; piracy is only the visible part of many other different criminal activities (Rinkel 2015: 4-5). However, numbers held by IMO indicate that piracy is on the rise (Leymarie et al. 2013: 34), with the increase of attacks in the high seas while attacks in territorial waters and ports are on the decrease. Since 2011 , numbers of attacks in the high seas surpassed those attacks in territorial waters and ports.

Concerning the issue of Maritime Security, the moves made towards securitization in the Gulf of Guinea follow the path of those made in Somalia, despite the distinct geopolitical character of that region. oseThe process follows a macrosecuritization process with several actors, ranging from the shipping industry and states and ending in the United Nations Security Council as the "higher-level" audience.

The importance of the region is acknowledge by the international community, and there is a perception of the threat posed by the lack of Maritime Security, leading to the promulgation of a resolution (UNSC, $2011)$ accepting the threat that piracy and armed robbery at sea in the Gulf of Guinea pose to international navigation, security and the economic development of states in the region. As in the case of Somalia (Oliveira 2015: 131), the threats identified could be good order at sea and a physical threat to environment, human life and propriety.

Moreover, this macrosecuritization process led to a series of strategies and plans to tackle the threats, such as the Africa's Integrated Maritime Strategy 2050, the Yaoundé code of conduct, the European Union (EU) strategy on the Gulf of Guinea and the EU Critical Maritime Routes 2014 (with a Gulf of Guinea Programme) (Otto 2014: 324), among many others. Mainly, the initiatives and operations off the coast of the Gulf of Guinea and West Africa have focused on deterring attacks and reducing threats to shipping through a focus on integration and naval capacity building (Walker 2013: 90). 


\section{Conclusion}

In sum, in this paper we have examined an argument that suggests that a process of securitization of Maritime Security in the Gulf of Guinea is on the move. First, the concepts of security and securitization were revisited to support the conceptualization of Maritime Security and the analysis of the securitization of this concept. We have demonstrated that there are different approaches to the concept of security and that it can be defined as "the absence of threats to acquired values" or "a low probability of damage to acquired values" and can be analyzed at different levels individual, state and international system - and in different dimensions - military, economic, political, environmental and social. Further, we've analyzed the process of securitization proposed by Buzan, Weaver and de Wilde and described the securitization process, recognizing that an issue brought up by an actor can lead to an existential threat perceived by an audience, but if there are no emergency measures or breaking of rules, it won't be securitized, remaining non-politicized or politicized.

The analysis of the concept of Maritime Security indicates that there is no consensus on finding a concept, however, it is mainly defined as the absence of threats in the maritime domain. Moving on to the process of securitizing an issue in the maritime domain, we've supported our analysis on the studies made on the securitization of piracy in Somalia, finding that the process was a macrosecuritization, targeting the UNSC as the "higherlevel" audience and reaching the desired effect with the promulgation of a resolution permitting international naval assets to tackle the threats within the territorial waters of Somalia.

Our analysis indicates that, due to its resources, the region of the Gulf of Guinea will increase in importance in the future and that it's dependency on sea-based transport, relying on open sea lines of communication and Maritime Security, will focus the international community on maintaining good order at sea in that region. Hence, the lack of capability to tackle the posed threats will require action from the international community. 
(I) In this context, a number of institutions are currently acting to secure the Gulf of Guinea, thus, a process of securitization of Maritime Security could be on the move. The production of resolutions, strategies and plans to deal with the threats focused on integration and naval capacity building indicates that the issue is part of public policy, and government decisions have been made and resources allocated, however, no emergency measures or breaking of established rules has occurred, thus, we can conclude that the issue remains politicized. 


\section{References}

Baldwin, D. A., 1997. The concept of security. Review of International Studies, 23: 5-26.

Barrios, C., 2013. Fighting piracy in the Gulf of Guinea: Offshore and onshore. European Union Institute for Security Studies Brief,:1-4.

Booth, K., 2007. Theory of World Security. Cambridge: Cambridge University Press.

Bueger, C., 2015. What is maritime security? Marine Policy, 53: 159-164.

Buzan, B., 1983. People, States, and Fear: The National Security Problem in International Relations. 2nd ed. Brighton, Sussex: Wheatsheaf Books.

Buzan, B. and Weaver, O., 2009. Macrosecuritization and security constellations: reconsidering scale in securitization theory. Review of International Studies, 35: 253-276.

Buzan, B., Weaver, O. and de Wilde, J., 1998. Security. A New Framework for Analysis. Boulder, Colo.: Lynne Rienner Pub.

Feldt, L., Roell, P. and Thiele, R. D., 2013. Maritime Security Perspectives for a Comprehensive Approach. ISPSW Publications. [online] Available at: <http://www.isn.ethz.ch/DigitalLibrary/Publications/Detail/? ots59 1 =0c54e3b3-1 e9c-be 1 e-2c24a6a8c7060233\&lng=en\&id=162756> [Accessed 6 Jan. 2015].

G7, 2015. Press Release: G7 Foreign Ministers on Maritime Security in Lübeck, 15 April 2015. [online] Available at: <http://www. new-york-un.diplo.de/Vertretung/newyorkvn/de/__pr/ Press_2Oreleases/2015/20150415-g7-foreign-ministers-on-maritimesecurity.html? archive $=2984636>$.

Jenkins, B. M. et al., 1983. A Chronology of Terrorist Attacks and Other Criminal Actions Against Maritime Targets. RAND Publications. [online] Available at: https://www.rand.org/content/dam/rand/ pubs/papers/2006/P6906.pdf [Accessed 10 Jan. 2015]. 
Kolodziej, E. A., 1992. Renaissance in Security Studies? Caveat Lector! International Studies Quarterly, 36(4): 421-438.

Leymarie, P. et al., 2013. UNOSAT Global Report on Maritime Piracy.

Oliveira, G. C., 2015. Securitização da violência privada no mar: a construção da pirataria somali como problema de segurança internacional. In: A. Barrinha and M.R. Freire, eds. Segurança, Liberdade e Política. Lisboa: ICS, pp. 107-140.

Otto, L., 2014. Westward ho! The evolution of maritime piracy in Nigeria. 13(3), pp. 313-329.

Rinkel, S., 2015. Piracy and maritime crime in the Gulf of Guinea : Experiencebased analyses of the situation and policy recommendations. Kieler Analysen zur Sicherheitspolitik, [online] (41). Available at: <http:// www.ispk.uni-kiel.de/de/publikationen/arbeitspapiere/sergerinkel-piracy-and-maritime-crime-in-the-gulf-of-guinea-experiencebased-analyses-of-the-situation-and-policy-recommendations>.

Till, G., 2009. Seapower. A Guide for the Twenty-First Century. 2nd ed. New York: Routledge.

United Nations, 1945. Charter of the United Nations. [online] Available at: <http://www.unwebsite.com/charter> [Accessed 2 Jan. 2015].

UNODC, 2013. Transnational Organized Crime in Eastern Africa: A Threat Assessment. [online] Available at: <http://www.unodc.org/ documents/data-and-analysis/Studies/TOC_East_Africa_2013.pdf>.

UNSC, 2008. Resolution 1816 (2008). Available at: <http://www.un.org/ press/en/2008/sc9344.doc.htm>.

UNSC, 2011 . Resolution 2018 (2011). [online] Available at: <http://www. un.org/press/en/2011/sc10430.doc.htm>.

Vreÿ, F., 2009. Bad order at sea: From the Gulf of Aden to the Gulf of Guinea. African Security Review, 18(3): 17-30.

Vreÿ, F., 2011 . Securitising piracy. African Security Review, 20(3): 54-66.

Walker, T., 2013. Maritime security in West Africa. African Security Review, [online] 22(2): 85-91. Available at: <http://www.tandfonline.com/ doi/abs/10.1080/10246029.2013.792552>. 
Walt, S. M., 1991. The Renaissance of security studies. International Studies Quarterly, 35(2): 211-239.

Williams, P. D., 2008. Security Studies. An Introduction. New York: Routledge. Wolfers, A., 1952. 'National Security' as an ambiguous symbol. Political Science Quarterly, 67(4): 481-502.

Lieutenant-Commander Joao Piedade is a military faculty member at the Institute of Higher Military Studies and a researcher at the Research Center of Security and Defence in Lisbon, Portugal. He is educated as a naval officer from the Portuguese Naval Academy and is a PhD candidate in International Relations at the Faculty of Social Sciences and Humanities of the Universidade Nova de Lisboa. His research interests focus on security studies, maritime security and forecasting. 